\title{
De zin en onzin van preventie in de huisartsenpraktijk
}

Citation for published version (APA):

van Schayck, C. P. (1998). De zin en onzin van preventie in de huisartsenpraktijk. Maastricht University. https://doi.org/10.26481/spe.19981218cs

Document status and date:

Published: 18/12/1998

DOI:

$10.26481 /$ spe.19981218cs

Document Version:

Publisher's PDF, also known as Version of record

\section{Please check the document version of this publication:}

- A submitted manuscript is the version of the article upon submission and before peer-review. There can be important differences between the submitted version and the official published version of record.

People interested in the research are advised to contact the author for the final version of the publication, or visit the DOI to the publisher's website.

- The final author version and the galley proof are versions of the publication after peer review.

- The final published version features the final layout of the paper including the volume, issue and page numbers.

Link to publication

\footnotetext{
General rights rights.

- You may freely distribute the URL identifying the publication in the public portal. please follow below link for the End User Agreement:

www.umlib.nl/taverne-license

Take down policy

If you believe that this document breaches copyright please contact us at:

repository@maastrichtuniversity.nl

providing details and we will investigate your claim.
}

Copyright and moral rights for the publications made accessible in the public portal are retained by the authors and/or other copyright owners and it is a condition of accessing publications that users recognise and abide by the legal requirements associated with these

- Users may download and print one copy of any publication from the public portal for the purpose of private study or research.

- You may not further distribute the material or use it for any profit-making activity or commercial gain

If the publication is distributed under the terms of Article $25 \mathrm{fa}$ of the Dutch Copyright Act, indicated by the "Taverne" license above, 


\title{
De zin en onzin van preventie in de huisartspraktijk
}

\author{
Rede
}

uitgesproken bij de aanvaarding van het ambt van bijzonder hoogleraar "Prevention Research in Primary Medical Care" vanwege de Stichting Annadal aan de faculteiten der Medische Wetenschappen van de Universiteit Maastricht en de Universiteit Nijmegen op 18 december 1998 door

\author{
Dr. C.P. van Schavck
}



Mijnheer de Rector Magnificus, leden van het Bestuur van de Stichting Annadal, leden van de Collegen van Bestuur en de besturen ran de faculteiten der Geneeskunde van de L'niversiteit ran Maastricht en ran de Lniversiteit ran Nijmegen, geachte collega's, geachte Dames en Heren,

\section{Yaorkomen is beter dan genterem?}

'oorkomen is beter dan genezen'. Een waarheid die niemand in essentie zal durven te bestrijden, zeker niet in de Geneeskunde. De patiënt, die mogelijk een bepaalde ziek te boren het hoofd hangt zal dit nuet doen; de dokter, die de consequenties van ziekten dagelijks ran dichtbij meemaakt, zal dit ook zeker niet doen; maar ook de zorgrerzekeraar en andere financiers van. onze gezondheidszorg, die jaar in jaar uit geconfronteerd worden met toenemende kosten, zullen deze stelling ook zeker niet bestrijden. Misschien dat er partijen zijn in onze gezondheidszorg, die vooral commercieel gebaat ziin bij de aanwezigheid van veel ziekten, maar deze partijen zullen dat nooit hardop durven zeggen. Hiermee zijn dus alle mogelijke tegenwerpingen tegen de stelling 'voorkomen is beter dan genezen' bij voorbaat de kop ingedrukt.

Ik zou hiermee dus mijn oratie kunnen beëindigen en we zouden over kunnen gaan tot de borrel die op ons te wachten staat. Ongetwjifeld zou dit een opluchting voor een aantal van de hier aanwezigen zijn. Echter, ik moet deze mensen helaas teleutstellen, want er valt -minns inziens-toch nog wat meer over preventie van gezondheid (en zeker over prevente in de huisartspraktijk) te zeggen Om deze mogelike teleurstelling enigszins te compenseren wil ik u hierbij beloven dat ik mijn 
uiterste best zal doen dit werhaal tot het einde toe boeiend te houden. Er zijn oraties waarbij slechts de eerste vijf en de laatste paar minuten te volgen zijn voor de leek. Ik zal een poging wagen om een verhaal te houden dat woor iedereen van het begin tot het einde te volgen is. Op zich moet dat niet echt een probleem zijin, want de meeste leken zijn tot op zekere hoogte deskundig (en in ieder geval ervaringsdeskundig) op het gebied van preventie van de (eigen) gezondheidszorg.

Ondanks het positieve oordeel over preventie dat vaak op voorhand wordt gegeven, is het feitelijk systematisch preventief geneeskundig handelen slechts in beperkte mate aanwezig bij de overwegend curatief opgeleide artsen. Artsen worden getraind in het herkennen van gepresenteerde klachten, om zo nodig over te gaan tot behandeling. Natuurlijk zullen artsen impliciet het nodige aan preventie doen, maar een arts is primair bezig met het aantonen of uitsluiten van ziekten bij individuen en weinig gericht op het voorkomen van ziekten bij die individuen. Bovendien hebben mensen die zich tot een arts wenden in het algemeen klachten en staan dus onder verdenking ziek te zijn. Het vereist een hele cultuuromslag (m.n. in de opleiding) om artsen meer te richten op preventie dan op curatie.

Daarnaast is het ook maar de vraag of de parient er zelf alrijd zo'n behoefte aan heeft om ongevraagd opgezadeld te worden met preventieve adviezen of handelingen van de dokter. Weliswaar zijn er commerciële medische bureaus, waarbij periodieke keuringen voor de 'worried well' uitgevoerd' worden. Hierbij is er echter sprake van een initiatie? door de patient (of misschien beter 'medisch consument") die gerustgesteld wil worden door een periodieke "grote beurt". Dit is zeker niet hetzelfde als preventief geneeskundig handelen op initiatief van de dokter. 
In de afgelopen jaren is de pathofrsiologische kennis van de meeste ziekten sterk toegenomen. Borendien beschikken we over rechnische mogelipheden on de aanwezigheid van een ziekte vroeg op te sporen en om deze gegevens te relateren aan mogelijke oorzaken. Door deze beide ontwikkelingen zijn de mogelijkheden roor preventief geneeskundig handelen sterk toegenomen. Deze toename heeft vele goede kanten maar heeft ook zijn schaduwzijde. Niet alle preventieve geneeskunde blijkt in de praktijk wenselijk te zijn. Er kan met recht gesproken worden over de zin en onzin van preventie. Maar hierover later meer.

\section{Onderdiagnostiek versus overdiagnastiek}

Bij veel chronische ziekien wordt de vergelijking met een ijsberg gemaakt. Alles wat boven het wateroppervlak ligi betreft ziekte die bekend is bij de arts (raak is dit de huisarts). Hierbij is dus al sprake van een diagnose. Als een ziekte in de bevolking toeneemt kan dit een aantal oorzaken hebben. Allereerst kan er sprake zijn van een werkelijke toename van de ziekte, d.w.z. de denkbeeldige ijsberg is in zijn geheel groter geworden. Maar er kan ook sprake zijn van een schijntoename, omdat de ijsberg niet werkelijk groter is geworden, maar het deel dat boven water uitsteekt, d.w.z. het deel van de ziekte dat ontdekt en gediagnostiseerd is door de artsen, is groter geworden. Dit kan weer veroorzaakt worden doordat artsen de aandoening eerder vaststellen (bijw. door verbeterde diagnostische testen) of doordat patienten zich tegenwoordig eerder melden (bijv. met privact-gevolige onderwerpen, zoals impotentie).

Nu lijkt deze laatste situatie aantrekkelijk. Inmers, we willen toch weten welle ziekte we onder de leden hebben om deze zo vroeg mogelijk te behandelen. Toch verdient deze oprie niet altijd de voorkeur. Het hangt er vanaf of het vroeg ontdekken van de ziekte uiteindelijk leidt tot een betere prognose, d.w.z. dat 
er een behandeling is die, als deze al in een vroeg stadium wordt ingezet, tor betere resultaten leidt dan wanneer dit in een later stadium gebeurt. Dit kan bijvoorbeeld omdat de ziekte een irreversibel verloop kent, waarbij de schade door uitstel van behandeling op termijn onherstelbaar is.

Enkele welken terug lieten Giard en Coebergh in een artikel in het Nederlands Tijdschrift voor Geneeskunde zien dat cen te grote diagnostische ijver bij artsen zijn keerzijde heeft. Zij illustreerden dit met behulp van een sterk schematisch verloop van een ziekte. Veel ziekten bij individuen verkeren in een subklinische fase voordat zij klinisch manifest worden, d.w.z. herkenbaar door klachten voor patient en dokter. Er kan in deze fase een spontaan herstel zijn of een verergering waardoor de ziekte werkelijk tot uiting kornt. De ziekte kan zich dan verder ontwikkelen of er kan een succesvolle genezing zijn. Vaak zullen er echter ook tussenfasen zijn, waarbij de ziekte al wel ontdekt kan worden $m . b . v_{\text {. }}$ een bepaalde gevoelige diagnostische test zonder dat de ziekte zich ook daadwerkelijk verder ontwikkelt. Deze gevoelige test is dus in staat om de aanwezigheid van voorstadia van een ziekte op te sporen op een moment dat de ziekte nog niet (volledig) aanwezig is (d.w.z. er zijn nog geen klachten). Dit is prima als we te maken hebben met voorstadia van een ziekte die zich normaliter verder zon ontwikkelen en bovendien genezen kan worden. Het is veel minder zinvol als we te maken hebben met de situatie dat de ziekte zich nooit daadwerkelijk verder zal ontwikkelen.

Deze laatste situatie is helaas niet denkbeeldig maar blijkt in de prakujk meer en meer op te treden. Een bekend voorbeeld is de toepassing van PSA (Prostaatspecifiek Antigeen) dat gebruikt wordt om prostaatkanker in een vroeg stadium op te sporen. Door PSA op grote schaal toe te passen verdubbelde de aanwezigheid van prostaatkanker in een deel wan de VS in een aantal jaren dijd. Dit is natuurlijk geen werkelijke verdubbeling, 
alleen de ziekte werd eerder opgespoord. In termen van het ijsbergfenomeen: de gehele berg komt meer boven water te liggen. Je zou ook kunnen zeggen: de klinische zeespiegel wn deze aandoening is verlaagd. Nou is het bij kanker in het algemeen zo dat het gunstig is als we de ziekte in een vroeg stadium opsporen. Bij andere, meer chronische ziekten als bijv. astma of COPD, hoeft dit echter niet het geval te zijn. Zo toonde onze onderzoeksgroep in Nijmegen recent in thet DIMCA-onderzoek aan dat het vroeg opsporen en vervolgens behandelen van patiënten met alleen de eerste aanwijzingen voor: astma en COPD mogelijk geen wezenlijke verbetering voor een deel van de patiënten oplevert. Ik kom later nog op dit voorbeeld terug. Het is niet onwaarschijnlijk dat er meer chronische ziekten zijn waarbij de vroege opsporing gerolgd door behandeling weing effectief blijkt.

Er speelt nog een ander probleem bij het vroeg ontdekken van ziekte door nieuwe gevoelige testen. Zoals Giard en Coebergh uitleggen in hun artikel kan een betere of vroege behandeling leiden tot een gunstige prognose, maar intensievere diagnostiek kan ook relatief meer lichte of indolente ziektegevallen opleveren (ook wel bekend onder het 'Will Rogers fenomeen'). Hierdoor lijkt het alsof relatief meer mensen genezen. Zo is de orerlevingskans na behandeling van borstkanker in Nederland sinds 1970 sterk verbeterd, terwijl de absolute sterfte aan borsthanker nagenoeg gelijk bleef. Dit kan dus verootzaakt worden doordat de ziekte eerder opgespoord wordt en die patiënten die opgespoord worden een betere prognose hebben. Deze goede prognose was bij die patiènten echter mogelijk ook zonder behandeling aanwezig geweest. Een schijnbaar beter behandelresultaat kan weer een anmoediging zijn om vroeger op te sporen en weer meer te gaan behandelen. Zo komen we dus in een vicieuze cirkel terecht. 
As deze ontwikkeling in onze maatschappil doorzet dan worden meer en meer mensen die naar hun eigen idee gezond zijn ontdekt met een mogelijke zickte onder de leden. Her gevaar van medicalisering van grote groepen van de bevolking dreigt. Bovendien is het gevaar niet denkbeeldig dat er op deze manier relatief steeds minder mensen zullen zipn die nog als 'gezond' beschouwd kunnen worden. "Een gezonde persoon is dan waarschijnlijk iemand die niet voldoende getest is." Om dit soort ontwikkelingen tegen te gaan is het van groot belang dat het natuurlijk beloop van ziekten in kaart gebracht wordt. Daarnaast moeten de nuttige effecten van vroegrijdige behandeling onomstotelijk aangetoond worden. Pas dan kunnen we zeggen wat de zin is van het vroeg ontdekken en eventueel behandelen van een ziekte, zonder dat we het gevaar lopen van medicalisering van de maatschappij.

Eigenlijk kunnen we stellen dat preventieve geneeskunde in de huisartspraktijk gekenmerkt wordt door het balanceren tussen twee uitersten: onderdiagnostiek (en daamee onderbehandeling) en overdiagnostiek (en daarmee overbehandeling). Als we spreken over zin en onzin wan preventie in de huisartsgeneeskunde gaat het er vooral om vast te leggen wat rationeel diagnostisch handelen van de huisarts is. Het verwijt dat regelmatig klinkt dat huisartsen hun patiënten niet tajdig diagnostiseren en daamee dus onderbehandelen is vaak afkomstig van specialisten in de tweede (of derde) lijn. Dit is volstrekt begrijpelijk vanuit het oogpunt waarmee je naar het probleem van preventie kijkt. Huisartsen zullen vooral beducht zijn voor de an screening inherente overbehandeling. Specialisten worden gealarmeerd door ernstig zieken die door de mazen van de screening zijn greglipt. Bij preventie is het dus belangrijk vast te stellen dat er een verschil is tussen het aanbod in patienten dat gezien wordt door de specialist ten opzicht van de huisarts. De specialist ziet een selectieve groep patienten warbij de kans veel groter is dat de ziekte al manifest is dan in 
van statistiek han men dan al bij roorbaat yoorspellen dat de huisarts een bepaald percentage van de paüenten niet zal ontdekken met het doel om orerbehandeling te roorkomen. As de huisarts alle mogelyke risicopatienten zou moeten opsporen en eventueel behandelen zou dit per definide overbehandeling in de hand werken.

\section{Cohlectiers presentis}

As we denken aan preventieve geneeskunde, dan ligt de associatie met gezondheidsrootlichting roor de hand. Dit wordt ook wel collectiere preventie genoemd. $\mathrm{Ke}$ worden bijna dageliks geconfronteerd met voorlichting over bijvoorbeeld gezonde roeding, veilig rrijen en stoppen met roken. Deze roorlichung gaat grotendeels ria de massamedia (bijroorbeeld postbus 51 -sponjes). Collectiere preventie is bijna zo oud als de mensheid. In een van de eerste boeken ran de Bijbel worden er al collectieve preventieve maatregelen voorgesteld om het besmetangsgeraar op verschillende infectieziekten zo laag mogelijk te houden. Tot in de kleinste details werden aanwijzingen gegeven hoe men zo min mogelijk in aanraking kon komen met iemand die besmet was, of met voorwerpen (bijroorbeeld kleren van een geinfecteerde patünt) die deze besmetting zouden kunnen oxerbrengen. Ook werden er allerlei aanwijzingen voor de voeding gegeven. Historisch kunnen we nier evalueren of deze voorlichang gewerkt heett. Whet weten we dat her foodse volksdeel in de Middeleeuwen ervan verdacht werd de pest te reroorzaken, omdat Joodse personen juist valk gespard bleven roor deze gevreesde ziekte. Achteraf gezien lijkt het niet onwaarschijlijk dat de voorschriften betreffende het niet eten van, of in aanraking komen mot ziekteverspreiders ecn belangriplie bijdrage geleverd heeft in het voorkomen van de pest bii de foodse berolking. 
Collectieve preventie heeft als woordeel dat het zich in her algemeen efficient laat organiseren. Grote groepen van de bevolking kunnen via goed opgezette programma's snel bereikt worden. Dit i.t.t de individuele preventie die veel meer op 'maat gesneden' dient te zijn en in her algemeen meer op het terrein van de huisarts ligt. Een goed voorbeeld van collectieve preventie is het tijkswaccinatieprogramma voor jonge kinderen. Jonge kinderen zijn als groep via het consultatiebureau of de school relatief gemakkelijk te bereiken. Wanneer middels dit programma een hoge vaccinatiegraad kan worden bereikt, vormt het aantal gevaccineerde kinderen als het ware een muur om de incidentele niet-gevaccineerden, zodat deze indirect ook beschermd worden. Zodra deze bescherming wegvalt, zien we vaak dat dit directe gevolgen met zich mee kan brengen. Een goed voorbeeld is de lokale poliomyelitis epidemie rondom een dorp op de Veluwe waar meerdere families om principieel religieuze redenen weigerden om hun kinderen in te enten tegen ziekte. Het feit dat preventieve maatregelen in de vorm van inenting nooit afgedwongen kunnen worden, kan directe gevolgen hebben voor de gezondheidszorg in het algemeen.

Collectieve preventie is dus alleen mogelijk wanneer er - maatschappelijk gezien- een breed draagvlak voor is en wanneer de overheid een actieve rol speelt. Dit laatste was het geval bij de bestrijding van een bepaalde schildklierafwijking (endemisch struma door jodiumdeficiënte voeding). Door jodium aan keukenzout toe te voegen verdween deze aandoenting geheel. Een heel ander verhaal was het toen in de zestiger jaren er ver ontwikkelde plannen waren om fluoride aan het drinkwater toe te voegen om zo tandcaries te verminderen. Dit is uiteindelijk niet doorgegaan omdat het matschappelijk draagvlak voor deze maatregel ontbrak. De ervoor in de plaats gekomen meer individueel gerichte preventie is wel zeer effectief gebleken (bijvoorbeeld de fuoride behandeling bij de tandarts of het toevoegen van fluor aan tandpasta). 


\section{Primaire, secundaire en tertiaire prepentie}

Collecrieve preventie is raak gencht op primaire prevende.

Primaire preventie heeft als doel ziekten bij gezonde mensen te roorkomen. Dit kan bijroorbeeld door mensen niet bloot te stellen aan een ziektehiem (bijwoorbeeld door te voorkomen dat bacterieel besmet water gedronken wordt) of door de afweer tegen ziekten te verhogen (bijvoorbeeld door vaccinatie). Er is bii primaire preventie dus nog geen ziekte aanwezig. Er kan al wel een aanleg voor een ziekte aanwezig zijn. Er wordt dus beoogd orm een primaire schakel in de keten van het ontstaan van een ziekte weg te nemen. Bif primaire preventie zoekt men vaak naar de zogenaamde risicofactoren voor een ziekte. WWanneer risicofactoren aanwezig zijn is de kans dat de ziekte op den duur manifest wordt groter dan bij personen die deze risicofactoren niet hebben.

Naast de primaire preventie bestaat ook de secundaire en de tertiaire preventie. Doel van secundaire preventie is het diagnostiseren en (zo nodig) behandelen van een ziekte in een rroege, herkenbare fase ran de ziekte. Het gaat hierbij om mensen die nog geen (of nauwelijks) klachten hebben, maar bij wie de eerste tekenen ran de ziekte al wel aanwezig zijn. Het doel is om te voorkomen dat er kjachten gaan optreden en de ziekte zich verder gaat ontwikikelen. Secundaire preventie kan plaatswinden door gericht onderzoek te doen naar de eerste aanwijzingen voor een bepaalde ziekte, bijvoorbeeld door "casefinding". Hierbij makkt de arts gebruik van een toch al plaatsvindend parënt-contact. Het kan ook door middel van screening, waarbij een groep personen speciaal voor dit doel wordt opgeroepen en onderzocht. Een voorbeeld van screening op vroege verschijnselen is de roegdiagnostiek van baarmoederhalskanker, warbij men de kankercellen opspoort roor zij door verdere uirgroei klinische verschijnselen kunnen reroorzaken. Een ander bekend voorbeeld is het bloedonderzoek bii pasgeborenen (de zgn. "hielprik") waardoor" 
een bepaalde stofwisselingsziekte in een vroeg stadium ontdekt kan worden.

Bij tertiaire prevente gaat het om het voorkomen van veretgering van een reeds aanwezige ziekte. Omdat het in deze fase vaak niet lukt om de ziekte te genezen is het doel om de gevolgen van de ziekte zo beperkt mogelijk te houden. Hoewel de scheidslijnen tussen de verschillende rormen van preventic niet in iedere siruatie even duidelijk zijn en de indeling in primair, secundair én tertiair de laatste tijd nogal ter discussie staat, is het vaak wel behulpzaam om deze indeling te hanteren. Omdat teriaire preventie een sterke overlap vertoont met de reguliere curatieve zorg zal ik mij in dit verhaal verder hoofdzakelijk beperken tot de primaire en secundaire preventie.

In het algemeen richt de huisartsgeneeskunde zich meer op tertiaire dan op secundaire preventie. En de huisartsgeneeskunde ticht zich in de huidige vorm weinig op primaire preventie. Dit hangt samen met het al genoemde feir dat de huisarts meew opgeleid wordt voor curatie dan voor preventie. Bovendien leent de huidige organisatie van de huisartsgeneeskunde zich beter voor curatie dan voor preventie. De huisarts reageert op klachten die gepresenteerd worden door de patiènt en gat in het algemeen niet zelf op zoek naar ziekten die zouden kunnen ontstaan of sluimerend aanwezig zijn. De huisarts heeft daar in de huidige praktijkorganisatie gewoon de tijd niet voor. Bovendien speelt hier een ethisch probleem. Het makkt veel uit of een patiënt met een op preventie gerichte hulprrag komt ("Dokter, kunt u mij cens helemaal doorlichten?") of dat het initiatief bij de arts ligt. Als cle patient et nict om varagt kan preventieve hulp (onbedoeld) schade opleveren: bezorgdheid bij de patiënt, bezorgdheid bij de familieleden, extra kosten die anders aan de curatieve zorg besteed hadden kunnen worden en mogelijk nadelige effecten van de testen die gebruikt worden. 
Orengens is het in dit kader interessant om een vergelijking te maken met de tandartsenzorg, warbij de curatieve zorg in de loop der jaren meer verschoven is naar de preventieve zorg. De "boordokter" is meer "controleur" geworden, waarbil periodicke controles en voorlichting gericht op preventie een essendeel onderdeel uimaken ran de dagelijkse tandheelkundige zorg.

\section{De ain ran preventief geneeskexndig handilen}

Of preventief geneeskundig handelen zin heeft hangt sterk af ran de situatie van de indiriduele patient. In reel situaties kan het middel (het rroeg opsporen en eventueel behandelen) erger zijn dan de kwal (de nog niet manifeste ziekte). Wanneer cen huisarts bij een 70 -jarige man een rectaal toucher verricht vanwege rectaal bloedverlies en hij roelt een hobbelige prostaat die mogelijk wijst op kanker stat hij voor een dilemma: moet er nu wel of geen actie ondernomen worden? Her verloop ran prostaatkanker laat zich moeilijk roorspellen. De kans is groot dat de kanker zich heel langzaam ontwikkelt en dat deze man uiteindelijk eerder met dan door kanker zal overlijden. De ongerustheid die bij de patiënt en de familie ongerwijfeld xolgt, zijn belangrijke schaduwzijden van deze vorm van preventie. Zoals het boek "Spreuken" al waarschuwr: "als iemand kennis vermeerdert, vermeerdert hij ook smart". Er zijn dus allerlei bedenkingen bij preventief handelen.

Als er al twifels zijn bij preventieve acriviteiten ten behoeve wan individuele parienten dan worden deze alleen nog maar sterker wanneer we op een macroniveau naar de preventieve gezondheidszorg kijken, dus niet op individu-mat op populacieniveau. Vaak wordt dan het eerst gedacht aan kosten. Natuurlijk zijn kosten een belangrijke overweging. Nu al moeten in onze overwegend curatiel ingestelde gezondheidszorg keuzen gemakt worden tussen her al dan niet vergoeden of stimuleren 
van verschillende (peperdure) behandelingen. Laat staan als hier de vaak uiterst kostbare preventieve programma's aan toegevoegd worden. Deze preventieve programma's kunnen op den duur soms kosten besparen, maar er zal eerst geinvesteerd moeten worden om deze programma's op te zetten.

Maar los van de kosten die preventie met zich meebrengt zijn er ook andere tegenwerpingen die op populatieniveau ingebracht kunnen worden tegen preventieve gezondheidszorg. Het lijkt erop dat in de westerse wereld de levensverwachuing bij de geboorte de biologische levensduur zo langzamerhand aan het benaderen is. Zoals al genoemd zullen oude mensen steeds vaker met dan door een ziekte overlijden. Fr wordt verondersteld dat de biologische levensduur van cellen (en dus van het individu) grotendeels geprogrammeerd is. Hierdoor zullen bepaalde personen -onafhankelijk van exentueel optredende ziekte en ongevallen- eerder sterven dan anderen. Op dit moment is de winst die te behalen valt als niemand meer zou overlijden aan kanker betrekkelijk klein. Om precies te zijn is deze winst in de leeftijdsgroep van 15-65 jaar slechts 7 maanden. De vraag is dan wat deze betrekkelijk geringe periode feitelijk toevoegt aan het leven? Natuurlijk gaat het bij dit soort globale berekeningen om gemiddelden over grote groepen mensen en kan de levenswinst voor een bepaald individu veel groter zijn. Men kan zich echter afvragen of een winst in levensduur niet van minder belang is dan de kwaliteit van leven van dit individu. Als kanker door preventieve maatregelen echt uitgebannen wordt zal de kwaliteit van leven ongetwijfeld toenemen, maar het zou ook kunnen zijn dat door preventieve activiteiten de mortaliteit ten gevolge van ziekte wel afneemt mat de Ceitelijke morbiditeit niet. Het gevolg zou dan zijn dat door preventieve activiteiten de algemene twaliteit van leven in de bevolking waarschijnlijk eerder afneemt dan verbetert. 
Dit brengt ons op een niet onbelangrijk ethisch zijspoor wat voortdurend meespeelt in vragen rondom preventieve geneeskunde. Steeds speelt de rraag wat het uiteindelike doel is tan preventieve geneeskunde: is her uiteindelijke doel het zo reel mogelijk reduceren van morbiditeit en mortaliteit of is het doel het rerhogen ran de kwaliteit van leven van de individuele patient? Vaak zal dit samen gaan, maar zeker niet altij. In de geneeshunde wordt er raak tanzelfsprekend vanuir gegaan dat morbiditeit en mortaliteit altijd een verslechtering van de kwaliteit van leven met zich meebrengt. In individuele gevallen hoeft dit echter niet zo te zijn. Als een pariënt door preventieve activiteiten langer leeft maar wel emstig gehandicapt blijkt zal dit de kwaliteit van leven in het algemeen verlagen. Omdat de kwaliteit van leven mede bepaald wordt door de instelling van de patiënt zelf dient de patient vanzelfsprekend zoveel mogelijk betrokken te worden bij beslissingen over preventief handelen. Nog lastiger echter worden de vragen als het beslissingen betreffen die over andere personen gaan. V'ruchtwaterpunctie als preventieve activiteit ten behoeve van screening op Downsyndroom is algemeen aanvaard. Is daarmee ook de rraag beantwoord of de kwaliteit wan leven van een "mongooltje" minder is dan het "nomale" broertje of zusje? Menig ouder die in een dergelijke situatie verkeert kan dit niet zonder meer bevestigen. Persoonlijk heb ik nooit in deze omstandigheden verkeerd, maar ik kan me wel voorstellen dat ouders vragen hebben over deze vorm van diagnostiek. Zo zou ik bijvoorbeeld zelf op grond van mijn eigen christelijke overtuiging niet aan dergelijke preventieve prenatale diagnostiek willen meewerken omdat ik geloof dat de kwaliteit van leven mare voor een beperkt deel bepaald wordt door de afwezigheid van ziekte. Ik denk dat het belangrijk is dat artsen hulp bieden bij het maken van wel overwogen eigen keuzen. 


\section{Preventie in de buisartggeneeskundige setting}

Terug naar de preventie door de huisarts. Hex is de vraag in hoeverre secundaire preventie en zeker primaire preventie tot het takenpakket van de huisarts zou moeten behoren. Het gaat er dus om een duidelijke scheiding aan te brengen tussen zinnig en onzinnig preventief handelen door de huisarts. Ik zal in mijn werdere betoog proberen aan te geven wat volgens mij criteria zouden moeten zijn in welke situaties de huisarts zich wel bezig zou moeten houden met secundaire en met primaire prevente. Verreweg het belangri|kste is naruurlijk of de preventie effectief (d.w.z. doeltreffend) is . Daamaast spelen kostenoverwegingen een rol (doelmatigheid) en de vrag of de preventieve activiteit inpasbaar is in de dagelijks huisartsgeneeskundige zorg (haalbaarheid).

Of cen preventieve activiteit van de huisarts doeltreffend is moet eerst door klinisch onderzoek bewezen worden. Er zijn momenteel enkele preventieve acuiviteiten die door de huisarts standaard verricht worden warvan de doeltreffendheid in mindere of meerdere mate bewezen is. Deze doeltreffendheid wordt echter per definitie in onderzoek geëvalueerd op populatie-niveau en niet op individu-niveau. In de afgelopen tijd hebben de meeste huisartspraktijken zich weer geworsteld door de jarlijkse griepprik. Honderden (relatief) gezonde personen (veelal 65-plussers) worden dan gevaccineerd. Hoe doeltreffend is deze vaccinatie? Onderzoek laat op overtuigende wijze zien dat griepvaccinatie bij personen ouder dan 65 jaar tot een verminderde sterfte leidt tijdens de griepperiode. Bovendien is angetoond dat de baten van griepvaccinatie groter zijn dan de kosten. Er zijn dus in de gezondheidszorg netto besparingen bij toepassing van de gricpprik. De vraag of een bepaalde individuele patient baat heeft bij een griep vaccinatie is daarmee echter nog niet beantwoord. Sterker nog: deze vraag zal feitelijk nooit beantwoord kunnen worden. Wanneer deze persoon namelijk geen griep krijgt zal het nooit helemaal duidelijk 
worden of dit ook niet was gebeurd als er geen griepprik was gegeven. Dit maakt het lasrig om de feitelike baten (op indridueel niveau) in te schatten. We spreken ook wel van de preventie-paradox: preventieve maatregelen op grote aantallen personen bliken uteindelijk maar roor een beperkte groep direct effect te sorteren. Dit gegeven vertalt zich voor een individuele patient in een risicoschatting: hoe groot is de kans dat deze persoon zal sterven wanneer hij of zij ajdens de eerstrolgende "griepgolf" griep knigt?

Kansschattingen zijn voor individuen een lastig gebeuren, zeker als het consequenties voor de eigen gezondheid aangaat. Wat betekent een kans van 1 op 10.000 dat je cen bepaalde ziekte zult krigen? Is die kans zo verwarloosbaar dat het onlogisch is actie te ondememen of juist niet? Yaak zullen allerlei irrationele orenwegingen bij dergelijke beslissingen een rol spelen (dit zijn overigens dezelfde irrationele orerwegingen waar de loterijen in Nederland groot door geworden zijn). Nou is deze beslissing niet zo moeilijk bil de griepprik: vaccinaties zijn algemeen geaccepteerd en de kans op vervelende bijwerkingen is gering. De huisarts zal de vaccinatie daarom aan iedere risicopatiën adwiseren. Dit wordt anders wanneer een preventieve maatregel de nodige moeite kost of de test, (bijroorbeeld bij het nemen ran een biopt bij rerdenking op kanker), of de matregel zelf mogelijke bijwerkingen geeft (zoals homonale therapie ter preventie ran aan osteoporose gerclateerde fracruren, waardoor er een verhoogde kans is op het optreden van borstkanker).

Ondarks de belasting en de risico's die kleven aan het nemen van een biopt zal een arts hierop aandringen (en een patiënt in het algemeen hier toestemming voor geven) omdat de gevaren die verbonden zijn aan de eventuele ontwikkeling van kanker zeer groot zinn. Bin de meeste chronische ziekten ligt dit minder duidelijk. Veel ziekten zim, niet direct fatal of zelfs helemal niet. In die siruaties zijn preventieve matregelen alleen 
aangewezen als de kans dat men de ziekte oploopt groot is. Een recent woorbeld waar de nodige commotie over ontstaan is, is de cholesterolscreening. Ongeveer twee jaar geleden stond op de voorpagina van een bekend Nederlands dagblad dat huisartsen hun patiènten belangrijke zorg ontzegden door te terughoudend te zijn ten aanzien van cholesterolscreening. Vele patienten zouden per jaar gemist worden doordat de berrolking niet op cholesterol gescreend werd. Het is bij cholesterolscreening belangrijk om een goed onderscheid te maken tussen personen met een hoog en een laag risico voor hart- en vaatziekten. Lijders aan familiaire hypercholesterolemie hebben een dermate hoog risico op hart- en vaatziekten dat opsporing en behandeling van deze groep roor zich spreekt. Maar naast deze - relatief kleine- groep zijn er zeer velen met een duidelijk verhoogd cholesterolgehalte warvoor het individuele risico zich veel moeilijker laat voorspellen. Dit risico is namelijk afhankelijk van een aantal andere factoren zoals bijvoorbeeld de leeftujd, bloeddruk en het rookgedrag. Voor de meeste personen onder de 50 jaar die geen hypertensie hebben en niet roken is de kans op een cardiovasculaire aandoening binnen enkele jaren zo gering dat het weinig zinvol is om cholesterol te bepalen. Waarschijnlijk is het zelfs weinig zinvol om deze groep cholesterol verlagende middelen te geven wanneer er wel sprake zou zijn van een duidelijk hoog cholesterol gehalte.

Om de doeltreffendheid van preventie dus zo hoog mogelijk te maken is het belangrijk om groepen te selecteren die het grootste risico hebben om de ziekte te ontwikkelen. Dit heeft een aantal zeer belangrijke voordelen:

1. De eventuele behandeling is effectiever.

2. De motivatie van de potentiele patiënten om deel te nemen aan preventief diagnostisch en therapeutisch handelen is doorgaans veel groter dan bij laag-risico patiènten. 
3. De kosten-effectiviteit rethouding is veel gunstiger (ondat personen met een laag risico nier onnodig hoeven te worden getest).

\section{Twee voorbeelden}

Hoe is nu de effectiviteit ran preventie in de eerstelijn te onderzoeken? Ik zal een en ander proberen toe te lichten m.b.v. van twee grote onderzoeksprogramma's die wij momenteel in Maastricht en Nijmegen uitroeren. Beide onderzoeksprogramma's zijn gericht op de preventie van astma in de huisartspraktijk. Het ene programma richt zich op pasgeboren kinderen (en is een voorbeeld van primaire preventie) en het andere progtamma ticht zich op rolwassenen (en is een roorbeeld ran secundaire preventie). In tegenstelling tot de eerder genoemde voorbeelden zoals griepvaccinatie en screening nat baarmoederhalskanker is de doeltreffendheid van de preventie ran astma nog absoluut niet aangetoond en zal de huisarts in het algemeen nauwelijks prerentief geneeskundig handelen om de ontwikkeling van astma bij kinderen of bij volwassenen te voorkomen.

\section{Het PREY ASK-programma (Preventie Van Astma bij} Kinderen) heeft to doel te onderzoeken of het ontstaan van astma bij kinderen roorkomen kan worden door presentieve maatregelen uit te voeren bij hoog-risico kinderen. Hiertoe worden +100 pasgeboren kinderen geselecteerd uit hoog-risico gezinnen, dw.z. gezinnen waarbij de rader, moeder, broer of zus astma heeft. Bij 200 kinderen worden preventieve maatregelen uitgevoerd, bij de overige 200 kinderen wordt de reguliere zorg gegeren. De preventieve matregelen worden deels in de zwangerschap, deels in de eerste levensjaren gegeven. Ze bestaan uit het roorkomen van blootstelling aan tabaksrook, huisstofmijt-, huisdier- en yoedingsallergenen. Liteindelijk wordr onderzocht of deze preventieve maatregelen het ontstaan van 
astma kunnen woorkomen. Als doelgroep kiezen we dus een groep kinderen die een relatief hoog risico heeft om astma te krijgen. Uit wooronderzoek weten we dat de aanwezigheid van astma bij eerstegraads familieteden hier een betrouwbare aanwijzing voor is. Astrma is namelijk een erfelijke ziekte. Of iemand astma kriigt is dus (ten dele) genetisch rastgelegd. Ongeveer $20 \%$ van alle kinderen heeft een dergelijk hoog-risico. Het risico om astma te krijgen is bij deze hoog-risico groep 3 tot 6 maal hoger dan bij andere kinderen. Het ligt voor de hand dat de doeltreffendheid van de preventieve maatregelen groter zal zijt bij deze groep. Bovendien zal deze groep meer gemotiveerd zijn de preventieve maatregelen uit te voeren (in het gezin weet men wat het is om astma te hebben) en de kosten die gemocid zijn met het uitvoeren van deze preventieve maatregelen zijn natuurlijk van beperktere omvang dan wanneer deze voor alle kinderen uitgevoerd moeten worden. Om nu tot een nog betere vaststelling te komen van de hoog-risicogroep zou men na de eerste screening op familiaire belasting (dus het voorkomen van astma bij eerstegraads familieleden) kunnen overgaan tot een genetssche screening waarbij (via bloedonderzoek) vastgesteld wordt of er een verhoogde kans is op de ontwikkeling van astma. Zo zou men dus kunnen komen tot het vaststellen van een zeer-hoog-risico groep. Dit is een van de doelen van dit PREVASK-onderzoeksprogtamma. Genetica is een zich zeer sterk ontwikkelend vakgebied waarvan de toepassing in de eerstelijns geneeskunde wel eens veel sneller zou kunnen gaan dan we op dit moment voor mogelijk houden. Toepassing hiervan zou mogelijk kunnen liggen in het selecteren van zeer hoog-risico groepen. We zijn momented bezig on het geboortecohort van hoog-risico kinderen te rekruteren. Ik kan dus nog weing van de resultaren van dit onderzoek vertelien. 
Het tweede lopende onderzoeksprogramma dat ik u als voorbeeld wil noemen -en war ik al even eerder an refereerdeis het DIMCA-programma (Detectie, Interventie, Monitoring van COPD en Astma). Dit programma heeft tor doel om bij volwassenen as tma (en COPD) in een vroeg stadium op te sporen, te vervolgen en te behandelen. Hiertoe zijn in het begin van de jaren negentig 1155 volwassenen willekeurig geselecteerd uit de open bevolking. Om de vroegste aanwijzingen voor astma miet te missen werd een test gebruikt waarbij niemand die aanwijzingen thad voor astma of COPD door de 'mazen van het net viel'. De opgespoorde personen met risicofactoren werden gedurende enige jaren vervolgd om vast te stellen of zich bij hen daadwerkelijk astma begon te ontwikkelen. Die patienten waarbij dit inderdaad het geval was werden vervolgens behandeld met ontstekingsremmers om de ontwikkeling van astma in een zo vroeg mogelijk stadium af te remmen of te voorkomen. Dit preventieve screenings-programma was in zoverre effectief dat er een geschikte test gebruikt werd die niemand met enstige aanwijzingen voor astma miste. Het nadeel van deze test was echter dat er nogal wat mensen door de test aangewezen werden waarvan nog maar moest blijken of ze echt ziek waren: slechts een deel wan de personen met een positicf testresultaat hadden op het moment van testen een zodanige vorm van astma dat ze direct in atanmerking kwamen voor behandeling. Van de overige personen met een positief screeningsresultaat bleek minder dan de helft in de loop der jaren astma te ontwikkelen. Dit betekent dat nogal wat personen onterecht 'opgezadeld' werden met een positief screeningsresultaat, zonder dat er daadwerkelijk wat an de hand bleek te zijn. Was deze preventie nou effecrie? Ja, zeker was deze effectief. Fr werd geen persoon gemist watrbij de ziekte zich aan het ontwikkelen was. Alle parienten die niet bekend waren bij de huisarts en die behandeld zouden moeten worden werden ook daadwerkelijk opgespoord. Maar hoe zouden al dic personen met een positief screeningsresultaat maat zonder 
astrma, deze preventieve activiteit ervaren hebben? Voor hen zal dit onderzock in de meeste gevallen inefficiënt en -mogelijkverontrustend zijn geweest. In onderzoekstermen had deze test een zeer hoge sensitiviteit maar een beperkte specificiteit. Was deze vtoege opsporing effectief in termen van uitgegeven kosten? De kosten per opgespoorde patiènt met een verlaagde longfunctie of een versnelde achteruitgang in longfunctie bedroegen ca. fl100.-. Dit bedrag is aanzienlijk lager dan het opsporen van een vrouw met baarmoederhals- of borstkanker. Een ziekenhuisopname van een patiënt met een emstige astmaaanval kost bovendien een veelvoud van dit bedrag. Het antwoord hangt af met welke bril je naar de resultaten kijkt.

Maar de belangrijkste toetssteen van het nut van preventie bii de vroege opsporing van astma is niet of patiënten opgespoord kunnen worden, maar of ze effectief behandeld kunnen worden. Zoals Wilson en Jungner al in 1968 stelden in hun inmiddels klassicke WHO-criteria waaraan een screeningsprogramma dient te voldoen: er moet een effectieve interventie zijn. Het heeft immers geen zin om personen op te sporen bij wie geen effecticve behandeling aangeboden kan worden. Momenteel wordt de laatste hand gelegd aan de beantwoording van deze vrang. In het DIMCA-programma is hierbij een onderscheid gemaakt tussen patiènten die op grond van een lage longfunctie en klachten direct behandeld dienden te worden en personen die een versnelde progressie van hun astma hebben (o.a. gemeten op basis van de longfunctiedaling). Belangrijk is om hierbii steeds te benadrukken dat geen van de opgespoorde patiënten ooit eerder door de huisarts gediagnostiseerd was als patient met astma. Tot nu toe blijkt uit de analyses die op dit moment vericht worden, dat ontstekingsremmers duidelijk effectief zijn bij die patiënten die op grond van een lage longfunctie en klachten direct behandeld werden. Bij de groep die een versnelde daling in longfunctie had lijkt er een onderscheid te zi|n tussen patiènten die een extreem snelle daling in longfunctie 
hadden en patiënten die een minder snelle daling hadden. Bij de eerste groep is de behandeling mogelijk effectief mar bij de laatste groep niet.

Hiermee zou men kunnen veronderstellen dat de doelmatigheid van vroege opsporing van astma (eventueel gevolgd door behandeling) bewezen is. Dir is echter nog net helemal waar. De laatste vraag die nu nog beantwoord dient te worden in het DIMCA-programma is de vraag: Wat was er gebeurd als de opsporing en dus ook de behandeling later had plaats gevonden, bijvoorbeeld op het moment dat de patiënt zichzelf met klachten op het spreekuur gemeld had bij de huisarts? Was er in dat geval sprake geweest van schade die niet meer hersteld zou kunnen worden als de behandeling pas op dat moment was ingezet? Deze vraag kan nog niet beantwoord worden omdat we dit nu aan het uitzoeken zijn: al die personen die een placebobehandeling gehad hebben in de hieraan vootafgaande onderzoeken worden nu alsnog behandeld met. ontstekingsremmers. Dir geldt ook voor de groep die in het onderzoek de echte behandeling gehad heeft. Vergeleken wordt dan uiteindelijk of de groep die pas later behandeld is met ontstekingsremmets, uiteindelijk op hetzelfde niveau van longfunctie kan komen als de groep die al eerder behandeld was. Als dit niet zo is, en er dus in feite onherstelbare schade opgetreden is in de longfunctie door een te laat ingezette behandeling, dan pas is echt bewezen dat deze vorm van preventie van astma echt doeltreffend en (in zekere zin) noodzakelijk is.

Uit bovenstaande voorbeelden blijkt hoe intensief (en daamee kostbaar) deze preventicve onderzoeksprogramma's zijn. Het eerste programma dat zich richt op kinderen (PREVASK) zal nog minimaal 10 jaar duren en zeker 55.000 .000 , kosten. 1 Het tweede wordt in het jaar 2000 afgerond en heeft dan ongeveer hetzelfde bedrag gekost. Men zou zich kunnen afvragen of deze 
inspanning de moeite echt waard is. Het zal u niet verbazen dat ik hier zonder enige aarzeling 'ja' op zeg. Ik zal u geruststellen dat achter deze bevestiging meer zit dan alleen een beroepsdeformatie. Ook als uit onderzoeksprogramma's blijkt dat de effectiviteir net in verhouding staat tot de lasten kosten, bezorgdheid bij deenemers en Eamilieleden, iatrogene effecten van diagnostiek of behandeling, etc) dan is dit zeer zinvol. Te makkelijk wordt namelijk geredeneerd vanui het al eerder genoemd adagium 'voorkomen is beter dan genezen' en wordt preventief handelen gepropageerd zonder dat dit in alle opzichten kritisch geëvalueerd is.

Uit de schaarse evaluaties die tot nu toe gedaan zijn op het gebjed van preventie kunnen we in het algemeen constateren dat preventie vaak moeilijk gerealiseerd wordt als individuen hun gedrag moeten wijzigen. Ons gedrag wordt voor een groot deel bepaald door onze ongeving. As iedereen rookt, zal elk tind leren roken. Recent liet de afdeling GVO van deze Universiteit zien dat mer name de ouders een belangrijke rol spelen in het rookgedrag van kinderen. Als alcohol op een feestie een 'must' is, zullen de meesten gaan drinken. Samenlevingsvormen veranderen relatief langzaam, maar op lange termijn kunnen effecten wel aanzienlijk zijn. Zo heeft het 30 jaar geduurd woordat roken van "norm tor zonde" werd. 


\section{Haalloarbeid van preventie in de eerstelin}

Tor nu toe hebben we hoofdzakelijk gesproken ower doeltreffendheid (een bewezen preventieve effectiviteit) en doelmatigheid (een bewezen kosten-effectiviteit) maar nog niet over haalbaarheid. In de praktijk $z a l$ het al dan niet uitvoeren van preventie in de huisartsgeneeskunde hiermee staan of vallen: Preventief geneeskundig handelen kan nog zo doeltreffend of doelmatig zijn, als het niet inpasbaar is in de dagelijkse praktijkvoering van de huisarts dan zal het nooit ingevoerd worden. Veel preventieve acriviteiten zïn uitermate ujdrovend. Het is belangrijk goed te overwegen of er cen reele implementatie mogelijkheid is in de huisartspraktijk. Ondanks de grote tijdbelasting is dit lang niet altijd onmogelijk. Veel van de preventicve activiteiten hebben een routinematig karakter. Daardoor lenen deze activiteiten zich uitstekend woor delegatie. In de praktrijk gebeurt dit bijvoorbeeld al vaak bij de controle van de bloeddruk en de suikerspiegel en de uitvoering van cervix-uitstrijken. Bij de controle op de follow-up (komt de patiënt zijn afspaken na, wordt de medicatie echt gebruike?) kan de praktijkassistente zeer goed ingezet worden. Het blijkt dat deze genoemde zaken vaak de onderdelen zijn waarop preventieve maatregelen in de praktijk verzanden. De implementatie van preventieve matregelen is meestal cen zaak van de lange adem. Onderzoek laat zien dat assistenten uitstekend ingezet kunnen worden voor voorlichringsaktiviteiten. Mogelijk kunnen deze activiteiten zelfs beter door de assistente dan door de arts gedaan worden, omdat de assistente in het algemeen minder geneigd is om snel tot (medisch) handelen over te gaan, maar de houding zal hebben on te luisteren en daarmee op maat gesneden informatie kan geven aan de patiënt. 
Wanneer we spreken over halbatheid is niet alleen de prakusche organisatie van belang maar ook de bekostiging van deze extra activiteiten. Elke activiteit kost de huisarts tijd en daamec geld. Dit betekent dat het niet reëel is om preventieve actwiteiten van de huisarts te verwachten wanneer deze niet bekostigd zullen worden. Het vergoedingssysteem dat tot dusverte in Nederland gehanteerd wordt, leent zich nauwelijks tot enige flexibilisering van betaling van de gezondheidszorg. Het systeem dat in Engeland al vele jaren succesvol loopt leent zich veel beter voor vergoeding van bijvoorbeeld extra (preventieve) activiteiten van speciaal opgeleide assistentes (bijvoorbeeld t.b.v. de 'asthma clinic' of 'diabetic clinic'). Mogelijk dat de toenemende betrokkenheid en invloed van zorgyerzekeraars in onze gezondheidszorg een toenemende flexibilisering van betaling van de gezondheidszorg met zich mee zal brengen. Verheugend is de ontwikkeling dat binnenkort zeer watschijnlijk een praktijkverpleegkundige vergoed gaat worden ten behoeve van iedere huisartsengroep $\operatorname{van} 3-4$ huisartsen. Hierdoor zal het prevenrief geneeskundig handelen door de huisarts veel makkelijker geïmplementeerd kunnen gaan worden.

Wanneer preventie overwogen wordt in het beleidsplan van de huisarts dan zijn in het algemeen de volgende vragen van belang:

- Is er cen interventie die doelmatig, doeltreffend en in de huisartspraktijk haalbaar is?

- Bestaat er een welomschreven hoog-risico groep van patiënten?

- Wegen voor de patiënt de kosten (in de zin van tujdsinvestering, risico's van diagnostiek en behandeling, emotionele belasting, etc.) op tegen de kans om de ziekte ook daadwerkelijk te krijgen?

- Is er binnen de beroepsgroep voldaende consensus over de toepassing van dit preventieve programma (bijroorbeeld neergelegd in NHG-standaarden)? 
De leerstoel "Prevention in primary health care" zal zich hoofdzakelijk bezig houden met de cerste drie vagen en wat minder met de latste vraag. Overigens zal het vaak zo zijn dat het antwoord op de eerste drie vragen al richting bepalend zal zijn voor de laatste rraag. De voorbeelden van de twee onderzoeksprogramma's die ik u gaf, proberen in verschillende deelonderzoeken antwoord te geven op de genoemde vragen.

\section{Swbidiologie}

Zoals ik $u$ al aangaf zijn de genoemde onderzoeksprogramma"s zeer langdurig en omvangrijk. Dit betekent ook dat er meerdere onderzoekers en onderzoeks-assistenten tegelijk aan een dergelijk programma werken. De langdurige dataverzameling en de personeelskosten van alle personen die bij deze programma's betrokken zijn, maken deze programma's bijzonder kostbaar. Het is een van de taken van de leerstoel on deze programma's gefinancierd te krijgen. Dit is niet eenvoudig. Veel subsidiegevers hebben niet de financiele middelen om dit te bekostigen. Subsidiegevers moeten vaak een keuze doen uit vele goede tot zeer goede onderzoeksvoorstellen. Als er een keuze gemaakt wordt woor één bepaald langdurig onderzoeksprogramma betekent dit bijna altijd dat verschillende andere onderzoeksprojecten niet gehonoreerd zullen worden. Dit is weinig antrekkelijk voor subsidiegevers die vaak zoveel mogelijk onderzoek zullen willen ondersteunen. Bovendien willen maar weinig subsidiegevers langdurige verplichtingen aangaan met onderzoeksgroepen. De meeste subsidietermijnen hebben een maximum van 4 jaar.

Tot dusverre is het nog steeds gelukt om de lopende onderzoeksprogramma"s in Maastricht en Nijmegen bijna volledig te financieren. 
Belangrijkste financiers in de genoemde onderzocksprogramma"s waren het Astmatonds, NWO Nederlandse Organisatie woor Wetenschappelijk Onderzoek), KNAW (Koninklijke Nederlandse Academie voor Wetenschappen), het Praeventiefonds en (diens opvolger) ZON (Zorgonderzoek Nederland) en de (farmaceutische) industrie.

Om deze subsidiegelden bij de verschillende sponsors te verkrijgen is een vak apart, waar je je als onderzoeksmanager noodgedwongen in moet bekwamen. Verschillende fondsen hebben verschillende spelregels, deadlines van indiening, hanteren verschillende teminologieën en format van onderzoeksaarvitagen.

In principe worden alle onderzoeksaanvragen bij de collectebusfondsen (de derde geldstroom) en bij de an de overheid gerelateerde fondsen, zoals NWO en KNAW (de tweede geldstroom) beoordeeld door een onathankelijke commissie dic hun oordeel grotendeels baseren op anonieme 'peer-reviews'. Bjj een dergelijke review worden de anvragen anoniem beoordeeld door collega-onderzoekers. Het idee achter de 'peer-review' is dat een onderzoeksaanvraag een eetijke en wetenschappelijk verantwoorde beoordeling krijgt. Helaas ervaren zij die al wat langer met "het subsidiebijlje hakken" veelvuldig de betrekkelijkheid hiervan. Vaak worden onderzoekers vanuit de door de overheid ingezette schaalvergroting en het streven naar een efficiëntere inzet van onderzoeksmiddelen sterk gestimuleerd om samen te werken met andere onderzoeksgroepen. Het aantal anonieme peers in ons kleine onderzoekslandje wordt hiermee dan tot een minimum gereduceerd. Vaak zijn 'peers' de enige echte concurrenten met (meestal) vergelijkbare onderzoeksideeën. Een objectieve extijke beoordeling ligt dan niet altijd in het verschiet, want niets menselifks is ook de onderzoeker vreemd. Vien internationale peer review kan soms een uitkomst bieden, mart lang niet altijd. De intemationale erkenning die dergelijke 
peers hebben maakt dat ze in principe nooit tijd hebben en bovendien weinig affiniteit hebben met dit onderzoek (of juist ook een negatieve affiniteit vanwege concurrentieoverwegingen) of (nog belangrijker) geen affiniteit hebben met de subsidiegever door wie ze gevraggd worden hun oordeel te geven.

Het is niet eenvoudig om een oplossing voor deze situatie te geven. Het door sommigen aangeprezen top-down model (waarbij de subsidiegever zelf meer actief onderzoeksgroepen benadert om onderzoeksprogramma's uit te voeren) is lang niet altijd een oplossing. Weliswaar hebben top-down programma's vaak meer financiële armslag waardoor volledige onderzoeksprogramma's in zijn totaliteit ondersteund kunnen worden, maar er kleven verschillende nadelen aan. Niet alleen kan de top-down benadering de kwaliteit van het onderzoeksplan verminderen omdat er sprake kan zijn van minder (of van zelfs helemaal geen) concurrentie, maar ook dreigt hier het gevaar van de 'achterdeurties politiek' waarbij door slim lobbyen individuen of onderzoeksgroepen elkaar "de bal toe kunnen spelen' door elkaar subsidiegelden toe te wijzen. Een ander nadeel is dat sommige belangrijke onderwerpen buiten de "top down' boot kunnen vallen.

Persoonlijk denk ik dat de beste oplossing ligt in het ondersteunen van samenhangende onderzoeksprogramma's dic in zijn geheel gesubsidieerd worden in de open competitie (dus bottom-up). In onderzoeksprogramma's lopen meerdere aan elkaar gerelateerde onderzoeksprojecten naast en na elkaar. Het is opvallend dat de wat grotere fondsen zoals bijwoorbeeld NWO en de Nederlandse Hartstichting hier de laatste jaren toe over gegaan zijn. Ik zou deze ontwikkeling sterk willen ondersteunen. De procedure is hierbij nog steeds bottom-up waardoor de genoemde nadelen van de top-down benadering niet aanwezig zijn, maar door de veel grotere financiële armslag. kunnen programma's in hun totaliteit ondersteund worden. Ik 
zou er voor willen pleiten dat andere fondsen (bijvoorbeeld ZON) meer trogelijkheden zouden creeten on volledige onderzoeksprogramma's gericht op de preventie van ziekte te ondersteunen.

\section{De leerstoel "Prevention in primary beallb care"}

Na dit subsidiologisch intermezzo zou ik nog kort een aantal zaken willen noemen met betrekking tot mijn leerstoel. De leetstoel "Prevention in primary health care" is een bevestiging van het onderzoek dat al welen voor mij gedaan hebben. Er ligt immers al een rijke traditie op het gebied van de anticiperende geneeskunde in de lauisartspraktijk. Bekende namen zoals Huygen, van den Dool, van Weel, van Ree, Thomas en Knottnerus hebben hier hun sporen al ruimschoots in verdiend. De instelling van deze leerstoel bouwt voort op deze traditie.

Mogelifk dat u tot dusverre de indruk heeft gekregen dat de leerstoel "Prevention in primary health care" louter betrekking heeft op de preventie van astma in de huisartspraktijk. De titel van de leerstoel zou de lading dan niet helemaal dekken. Dit is niet het geval. Weliswaar is het historisch zo gegroeid dat de onderzoeksprojecten waarvan ik de afgelopen 10 jaar projectleider was, hoofdzakelijk betrekking hadden op astma en COPD. De afgelopen jaren is er echter een aantal boeiende nieuwe onderwerpen bijgekomen: dit betreft de prevente van prostathypertrofie, artrose en langdurig psychische vermoeidheid in de arbeidssituatic. Hoewel deze aandoeningen geheel anders van aard zijn, zijn wak dezelfde principes betreffende preventie toepasbaar zoals ik u die geschetst heb bij astma en COPD. Vele chronische aandoeningen kennen een preklinische fase die, wanneer deze in een vroeg stadium vastgesteld wordt, mogelijk effectief behandeld kan worden. 
Hiermee is bij deze leerstoel dus sprake van een typische generieke aanpak die kenmerkend is voor de cerstelijns geneeskunde. Dat wil niet zeggen dat er alleen vanuit de eerstelijns geneeskunde gewerkt zal worden. De afgelopen jaren heb ik ervaren dat juist de samenwerking tussen de eerste en tweede lijns geneeskunde buitengewoon vruchtbaar is. De goed ontwikkelde meettechnieken en hypothetische mechanismen die veelai bedacht worden in de specialistische zorg, worden vaak alleen toegepast bij een beperkte groep van relatief emstige patiënten, die doorverwezen zijn naar de specialist. Meer en meer is men ervan overtuigd dat ziekten pas goed onderzocht kunnen worden als alle ernstgraderingen van een bepaalde ziekte onderzocht worden. Steeds vaker blijkt dat conclusies die gebaseerd zijn op ziekenhuispopulaties nier volledig van toepassing zijn voor patiënten met lichtere vormen van een ziekte. Dit geldt natuurlijk zeker voor preventie. Een goede samenwerking bij onderzoek in de eerste en tweede lijn ligt dan ook voor de hand en zal vaak tot wederzijds voordeel strekken. Dit komt ondermeer tot uiting in het feit dat het initiatief voor deze leerstoel ligt bij de Stichting Annadal, die hiermee vanuit de tweede lijn het eerste lijns onderzoek mede ondersteunt. Ik ben de Stichting St. Annadal dan ook bijzonder erkentelijk dat zij de leerstoel heeft ingesteld. Ik heb zelf in de afgelopen jaren een buitengewoon goede samenwerking ervaren met de Vakgroep Longziekten van het AZN, Het Medisch Centrum Dekkerswald en meer recent met de Afdeling Pulmonologie van het AZM. Meerdere succesvolle projecten zijn uit deze samenwerking tot stand gekomen. Evenzo is er een goede samenwerking gaande met de afdeling Urologie van het $A Z M$ en is er een jarenlang preventie-gerichte samenwerking met de afdelingen Interne Geneeskunde en Cardiologie van het AZM. Ik hoop dat deze samenwerking zich de komende jaren zal uitbreiden naar andere klinische capaciteitsgroepen. 
Er zijn verschillende mensen die mij gevraagd hebben hoe het is on te werken als hooglenat aan twee Universiteiten. De leerstoel is ingesteld binnen de Onderzoeksschool Netherlands School of Primary Care Research, waat zowel het Maastrichtse Onderzocksinstituut for Extramural and Transmural Health Care als de Nijmeegse Vakgroep Huisarts- Sociale- en Verpleeghuisgeneeskunde deel van uitmaken. Hierdoor is het o.a. mogelik om gebruik te maken van de twee huisartsregistratiebestanden van de twee vakgroepen, hetgeen ongekende mogelijkheden geeft voor de grotere onderzoeksprojecten. Er zijn al enkele projecten opgezet die momenteel gebruik maken van deze twee grotere registratiebestanden.

Na enkele jaren op twee plaatsen gewerkt te hebben kan ik u zeggen dat het fascinerend is om te zien hoe verschillend de cultuur is, niet alleen aan de twee Universiteiten, maar ook in de twee Vakgroepen. Ik ervaar het werken op twee platsen persoonlijk wel als cen spagaat. Nu heb ik tot dusverre weinig ervaring opgedaan in mijn leven met baller en heb daar ook niet echt ambities voor, maar ik merk wel dat ondanks dat een spagaat er heel kunstig uit kan zien, het op den duur wat vermoeiend en gezinsonvriendelijk is.

\section{Danks}

Ten slotte een dankwoord. Naast de Stichting Annadal die ik al gerroemd heb gat mijn dank uit naar het bestuur van de Medische Faculteiten wan de Universiteit van Mastricht en van de Katholieke Universiteit Nijmegen. Ik dank u roor het vertrouwen dat u als bestuur in mij stelt door mij te benoemen als hoogleraar. Er zijn ook heel veel personen war ik erg ved aan te danken heb. Ik wil ze nu niet allemaal noemen. $1 \mathrm{k} z \mathrm{zal}$ de meesten van hen vanavond in een wat kleiner gezelschap noemen. Ik wil me nu slechts beperken tot enkele personen: 


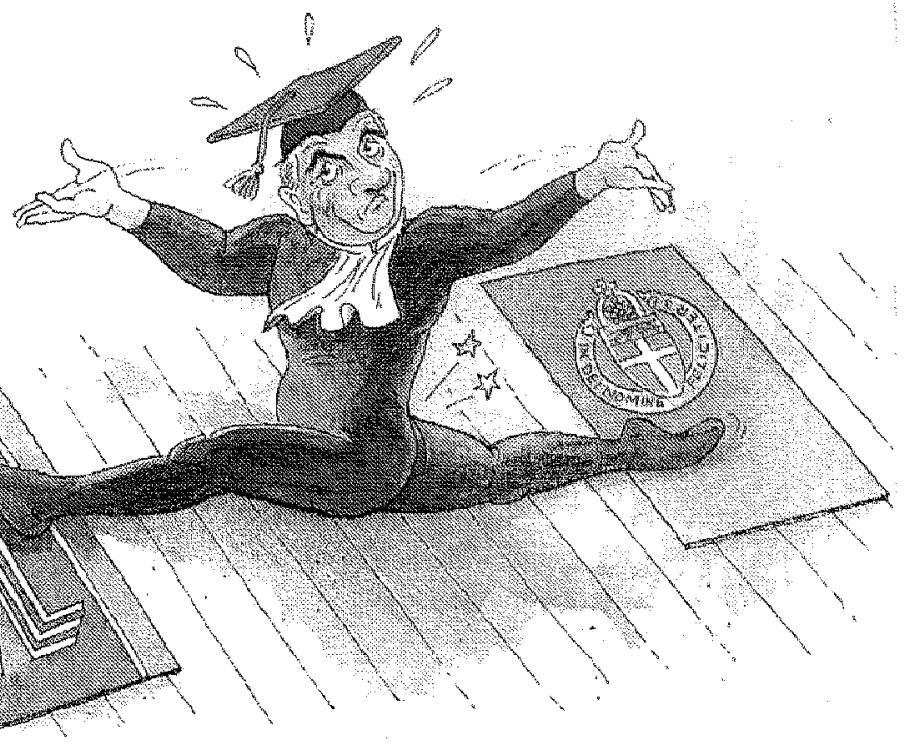


Ik wil mijn promotores Chris van Weel, Cees van Herwaarden en Hans Folgering bedanken woor wat ik van hun geleerd heb tijdens mijn promotie en daama. Dank voor het vertrouwen wat jullie in me hebben gesteld door zelfstandig een onderzoekslijn. op te kunnen zerten.

Daatnaast wil ik André Knottnerus bedanken. Dank je André dat je aan de wieg gestaan hebt van deze leerstoel. Ik kijk met veel warmte terug naar dat gesprek dat we een aantal jaren terug hadden in een café in Well. Ik was toen op een tweesprong beland en had warschijnlijk voor een carrière in heel andere richting gekozen als jil mij geen nieuwe mogelijkheden had aangeboden. Andre ik vind het buitengewoon plezierig om met je te werken en hoop dat nog vele jaren te kunnen doen. Ik ken geen onderzoekers die zo motiverend en inspirerend zijn als jij. Ik denk bovendien dat de Universitaire wereld er sterk bij gebaat zou zijn als er meer onderzoeksmanagers zouden zijn zoals jiij.

De laatste persoon die ik wil bedanken is mijn vrouw, Comel. Dank je Cornel, voor al je ondersteuning in de afgelopen jaren. Dank je dat je me regelmatig corrigeerde als ik teveel in een bepaalde richting doordraafde. Ik besef heel goed dat ik de afgelopen jaren niet had kunnen doen wat ik gedaan heb als jij er niet geweest was.

Dames en Heren, ik heb $u$ aan het begin van deze oratie een borrel in vooruitzicht gesteld. Ik zal niet langer van uw tijd nemen. Er is veel Gascinerend onderzoek gaande naar de risico's van alcohol met betrekking tot het ontstaan van chronische zickten. Nog veel fascinerender zijn vaak de onderzoeken naar de positieve preventieve effecten van een borrel op zijn tijd op her ontstaan van chronische ziekten. Het lijkt mij echter beter om dat tijdens de borrel te bespreken dan daarvoor.

Ik heb gezegd. 


\section{Geraadpleegde literatuur}

Aalderen HJ van, Knottnerus JA. Is de huisarts in staat preventieve taken op zich te nemen? Huisarts Wet 1978; 21: 424-7

Bergen JEAM van. Preventie van sexueel overdraagbare infecries. Medisch Contact 1996;51:84-8

Boom $G$ van den, Schayck CP van, Rutten-van Mölken MPMH, Tirimanna PRS, Otter JJ den, et al. Acrive detecrion of COPD and asthma in the general population: results and economic consequenses of the DIMCA program. Am J Respir Crit Care Med 1998 (in press)

Boot CPM. De zin van interventie bij risicofactoren voor harten vaatziekten. Arrikelenreeks in Medisch Contact, 1987

Boot CPM, Thomas S. Wanneer is behandeling van een hoog serumcholesterol zinvol? Medisch Contact 1997; 52: 1348-55

Bijblijven. Preventie als aandachtsgebied in de huisartspraktijk. Bohn Stafleu Van Loghum B.V., Houten, 1995; 11: 2

Dool CWA van den. Anticiperende geneeskunde: Huisarts Wet 1970; 13: 59

Editorial. Schould we screen for prostate cancer? $\mathrm{Br}$ Med J 1997; 314: 989-90

Feinstein AR, Sosin DM, Wells CK. The Will Rogers phenomenon. Stage migration and new diagnostic techniques as a source of misleading statistics for survival in cancer. New Engl J Med $1985 ; 312: 1604-8$ 
Fijren $\mathrm{GH}$. Rectal bleeding, a danger signal? Dissertane. Maastricht, 1993

Gercama A, Schayck van CP, Croone-Kraaijeveld E. Hoofdstuk 9: Preventie. Grundmeijer H, Reenders K, Rutten G. In: Het medisch proces. Utrecht: Bunge 1999

Giard RWM, Coebergh JWW. De keerzijde van diagnostische ijver. Ned. Tijdschr Geneeskd 1998; 142:2187-90

Grunsven PM van, Schayck CP van, Kollenburg HJM, Bosheide $\mathbb{K}$, Hoogen HJM van den, Molema J, Weel $\mathrm{C}$ van. The role of "fear of corticosteroids" in non-participating to the DMCA projects (an early detection, monitoting and intervention program in asthma and chronic obstructive pulmonary diseases (COPD)). Eur Respir ] 1998; 11:1178-81

Huygen FJA. Anticiperende geneeskunde, een nieuwe denkwize. Huisarts Wet 1971; 14: 447

Knottnerus IA. Interpretatie van diagnostische gegevens. Theoretische en praktische bijdragen aan de diagnostische epidemiologie in de extramurale gezondheidszorg. Dissertarie. Maastricht 1986

Knotnerus JA, Gtinten $\mathrm{R}$ van de. Huisarts en epidemiologie. Wetenschappelijke Uitgeverij Bunge, Utrecht 1994, pag. 76-77. ISBN 0063482183

Knottnerus JA. Toekomstige ontwikkelingen in de huisartsgeneeskundige wetenschap. Het Medisch Jaar 1997, pag. $1-23$

LHV-NHG-werkgroep Preventie. Concept-voorstel inzake preventie in de huisartspraktijk. Utrecht, 1992 
Medical Research Council Working Party. MRC trial of treatment of mild hypertension: principal results. Br Med J 1985; 291: 96-104

Mudde AN, Vries H de. "Stoppen met roken" advisering in de artsenpraktijk. Medisch Contact 1997; 52: 789-90

NHG-Standaard Hypertensie (M17). In: Rutten GEHM, Thomas S, red. NHG-Standaarden. Utrecht: NHG / Bunge. 1993

Pieterse ME, Duistermaat JH, Drenthen AJM. Minimale interventiestrategie in de huisartspraktijk. Medisch Contact 1997; 52: $791-2$

Raad voor Gezondheidsonderzoek. Prioriteiten in preventieonderzoek. Onderzoeksverslag Instituut Maatschappelijke gezondheidszorg EUR/TNO Preventie en gezondheid. 's Gravenhage, april 1996

Ree JW van. Naar preventie op maat. Inaugurale rede. Maastricht, 1990

Rose GA. Rolle of controlled trials in evaluating preventive medicine. London: Pitman, 1985

Sackett DL, Haynes RB, Guyatt GH, Tugwell P. Clinical epidemiology, a basic science for clinical medicine. Boston: J.ittle, Brown, 1991

Schaapveld K, Jirasing RA. Preventiegids. 1997, Van Gorkum, Assen 
Schönberger HJAM, Schayck CP tan. Prevention af asthma in genetically predisposed children in primary care. From clinical efficacy to a feasible intervention programme. Clin Exp Allergr 1998; 28: $1325-31$

Skrabanek P, McCormick J. Follies and fallacies in medicine. Glasgow: Tarragon, 1989

Sturmans F, Verbeek A. Argumenten voor en tegen bevolkingsonderzoek. Bijblijven 1986; 2: 6-18

Thomas S. Transparante geneeskunde. 1997 uitg. de Woordenwinkel Utrecht

Tijmstra Tj. Kennis maakt verantwoordelijk. Medisch Contact $1997 ; 52: 1578-1581$

Tirimanna P. Active detection of obstructive airways disease in the general population. Thesis, Nijmegen, 1997

Weijden T. van der. Evaluation of cholesterol guidelines in general practice. Thesis Maastricht, 1997

Wilson JHG, Jungner G. Principles and practice of screening for disease. Geneve: WHO, 1968

Zola IK. The omnipresence of illness. Huisarts Wet 1973; 16: 427 